\title{
Voz e fala de Parkinsonianos durante situações de amplificação, atraso e mascaramento $* * * *$
}

\author{
Voice and speech of individuals with Parkinson’s Disease during \\ amplification, delay and masking situations
}

\author{
Sylvia Boechat Coutinho* \\ Giovana Diaféria** \\ Gisele Oliveira*** \\ Mara Behlau****
}

\section{*Fonoaudióloga. Mestre em Fonoaudiologia pela Pontifícia Universidade Católica de São Paulo. Endereço para correspondência: Rua Icarahy da Silveira 360/404 Bl.1 - Rio de Janeiro - RJ - CEP 22630-060 (sylviabc@hotmail.com). \\ **Fonoaudióloga. Especialista em Voz pelo Conselho Federal de \\ Fonoaudiologia com o Curso no Centro de Estudos da Voz (CEV). \\ Coordenadora do Serviço de \\ Fonoaudiologia na Associação Brasil Parkinson (SP). \\ ***Fonoaudióloga. Mestre em Distúrbios da Comunicação Humana pela Universidade Federal de São Paulo. Professora do Curso de Especialização do CEV. \\ ****Fonoaudióloga. Doutora em Distúrbios da Comunicação Humana pela Unifesp. Professora do Curso de Especialização do CEV.}

****Trabalho Realizado no CEV.

Artigo Original de Pesquisa

Artigo Submetido a Avaliação por Pares

Conflito de Interesse: não

Recebido em 08.04.2008.

Revisado em 09.01.2009; 26.02.2009; 06.08.2009.

Aceito para Publicação em 25.08.2009.

\begin{abstract}
Background: individuals with Parkinson's disease present voice and speech alterations, especially regarding loudness and speech rate. Aim: to determine the immediate effect of modified auditory feedback: amplification, delay and masking in the voice and speech of individuals with Parkinson's disease, according to gender. Method: twenty-six subjects with Parkinson's disease (15 men and 11 women) with ages ranging between 40 and 86 years (mean age of 69 years) participated in the study. The speech material consisted of the counting from twenty to zero, four times, in four different listening conditions: habitual, amplified, delayed and masked. The following parameters were selected for the auditory-perceptual analysis: vocal quality, loudness, pitch, overall strain level, speech rate and articulation. The assessment was carried out by five Speech-Language Pathologists specialists in voice. The following parameters were selected for the acoustic analysis: fundamental frequency, intensity and maximum phonation time. Results: regarding the auditory-perceptual analysis, an improvement in vocal quality, increase in loudness and overall strain level was observed in the masking situation. On the other hand, a decrease in vocal quality, a decrease in loudness and overall strain level, a decrease in speech rate and in articulation precision was observed in the amplification and delay situations. In the acoustic analysis, an increase in the fundamental frequency and vocal intensity was observed in the masking situation and an increase of the maximum phonation time was observed in the delay situation. Conclusion: the masking situation presents better immediate effect in the voice and speech of individuals with Parkinson's disease while the amplification and delay situations do not produce satisfactory immediate modifications.
\end{abstract}

Key Words: Parkinson’s Disease; Voice; Speak; Hearing.

\section{Resumo}

Tema: indivíduos com doença de Parkinson apresentam alterações de voz e fala, principalmente em relação à loudness e velocidade de fala. Objetivo: verificar o efeito imediato do monitoramento auditivo modificado: amplificação, atraso e mascaramento na voz e fala de indivíduos com doença de Parkinson, de acordo com os sexos. Método: 26 indivíduos com doença de Parkinson, 15 homens e 11 mulheres, com faixa etária entre 40 e 86 anos e idade média de 69 anos. O material de fala consistiu na contagem de vinte a zero, quatro vezes, em quatro diferentes situações de escuta: habitual, amplificada, atrasada e mascarada. Para análise perceptivo-auditiva foram selecionados os seguintes parâmetros: qualidade vocal, loudness, pitch, nível geral de tensão, velocidade de fala e articulação. A avaliação foi realizada por cinco fonoaudiólogas especialistas em voz. Para a análise acústica foram selecionados os seguintes parâmetros: freqüência fundamental, intensidade e tempo máximo de fonação. Resultados: Por meio da análise perceptivo-auditiva, verificou-se melhora da qualidade vocal, aumento da loudness, maior tensão e melhor articulação na situação de mascaramento; piora da qualidade vocal, redução da loudness, menor tensão, lentificação na velocidade de fala e piora na articulação nas situações de atraso e amplificação. Na análise acústica, observou-se aumento da freqüência fundamental e intensidade vocal sob mascaramento e aumento do tempo máximo de fonação sob atraso. Conclusão: A situação de mascaramento produz melhores efeitos imediatos na voz e na fala dos indivíduos com doença de Parkinson e as situações de amplificação e atraso não produzem modificações imediatas satisfatórias.

Palavras-Chave: Doença de Parkinson; Voz; Fala; Audição. 


\section{Introduction}

Parkinson's disease (PD) is a neurodegenerative condition characterized by tremor at rest, akinesia, muscular rigidity and postural instability. Although loss of neurons can occur in other structures of the brainstem, the main abnormality is a degeneration of neurons in the substantia nigra that project to the striatum. The speech alteration is the most frequent motor manifestation 1.

Individuals with PD may present voice, speech and even language alterations, besides difficulties in swallowing. Such communication problems may favor social isolation. The vocal intensity is usually decreased and the voice can be hoarse 2 , with an additional swallowing impairment caused by weakness of laryngeal valve3. Some individuals with PD may present increased speech rate in utterance segments alternated with segments of decreased speech rates, which can negatively interfere on the intelligibility of the message 3 . For some patients, especially in more advanced levels of the disease, a cognitive impairment may be associated 1-3.

Traditionally, the speech and language treatment for speech alterations of individuals with Parkinson involves three distinct approaches: muscle therapy, coordination of speech structures, and breathing. Treatment is usually carried out once or twice a week, emphasizing articulation, speed and prosody 4.

The literature shows evidence of level I for Lee Silverman Voice Treatment (LSVT $®)$ rehabilitation method, deloped by Ramig et al 5. This method focuses on the laryngeal level for treatment of voice and speech impairments of individuals with PD. Although this method is considered the best one to rehabilitate individuals with PD - and there are clear indications for its administration - other rehabilitation strategies, such as manipulation of auditory feedback, exist 6 . The later strategy is based on the immediate impact that a change in the listening condition of one's own voice causes on the vocal production. Such modification can be a great resource for voice treatment once it can promote changes in intensity, articulation, speed, phonation, prosody, rhythm, frequency and resonance. This monitoring can be modified in several manners, among them: amplification, delay and auditory masking. The amplification produces an immediate reduction of vocal intensity, an easier and stable emission, less strained voice quality, and longer Maximum Phonation Time (MPT) 6. The delay produces the Lee effect. This effect consists on the speech with auditory stimulation reproduced to the ears of the individuals with a delay of fractions of seconds. Such effect propitiates the reduction of the speech rate 6-7. The masking allows the production of a reflex response - known as Lombard effect. This effect is the tendency to increase vocal intensity in noise, once the noise prevents one from listening his own voice 6-11.

As individuals with PD present voice and speech alterations, the purpose of the present study is to examine the immediate effects of the modified auditory feedback on selected aspects of the emission through auditory amplification, delay and masking, according to gender.

\section{Método}

This study was carried out from August, 2005 to July, 2006, at the Brazil Parkinson Association (Associação Brasil Parkinson- BPA), in the state of São Paulo. The research project was approved by the Research Ethics Committee of the Voice Study Centre (Centro de Estudos da Voz - CEV) under protocol number 3012/04. All subjects agreed to participate in the study and signed a Free and Informed Consent Form.

Twenty-six individuals (15 men and 11 women) with ages ranging between 40 and 86 years (mean age of 69 years) participated in the study. The inclusion criteria were: to present Parkinson's disease level 2 - according to the Modified Hoehn and Yahr Scale 12 - as diagnosed by a neurologist; and to present hearing assessment results within normal limits or mild or moderate hearing loss - as proposed by Davis and Silvermann 13; assessment that excluded alterations other than those related to PD (such as reflux, and Reinke's edema); and Speech-Language Pathology screening that revealed mild or moderate voice alteration, according to the GRBAS scale 14 , where G corresponds to the overall level of voice alteration, $\mathrm{R}$ to roughness, B to breathiness, A to asteny, $\mathrm{S}$ to strain, and I to instability . Regarding the severity level, 0 corresponds to absent or normal, 1 to mild, 2 to moderate, and 3 to severe. Individuals with voice alteration - such as palilalia and festinating speech - and absence of language impairments that would compromise communication and execution of required tasks were included in the study. Such impairments were analyzed through verbal language observed during the formal initial interview with patients. It was asked to the subject to remember and answer to the following questions: about personal data (name, age, date of birth, 
address and telephone number); history of PD (complaint, duration, signs and symptoms, data on drug use); and general health condition.

The subjects were receiving medication according to the intensity of their symptoms through the use of: selegiline, anticholinergics, amantadine, levodopa and dopamine agonist. During the study period, all subjects were at the ON period of medication, according to statement provided by their neurologists. The subjects were receiving Speech-Language Pathology treatment with the same routine of intervention, monitoring and frequency. Subjects with parkinsonism-plus were excluded from the study. Parkisonism -plus refers to a group of degenerative diseases that are expressed by akinetic-rigid syndrome associated with other neurological manifestations usually not observed in PD 15.

For recording of the speech material, an HP Pavilion laptop, model 4940 and PCZE sound card with output of $120 \mathrm{~dB}$, a LeSon Condenser MP-68 Microphone Cardioid and a Leadership Group headset were utilized. The software Fono Tools (version 1.5h, CTS Informática) was used for listening conditions with the pre-amplifier of the system and with the following functions activated: amplification, delay and auditory masking.

For each individual, the speech material collected consisted of the counting of numbers from twenty to zero, four times, in four different listening conditions: habitual, amplified, delayed and masked. The recording sequence of the tasks was the same for all participants. Recordings were carried out with the individual sitting in silent environment (noise intensity lower than $50 \mathrm{~dB}$ - as measured by the Realistic sound pressure meter from Radio Shack) with headphones and the microphone positioned at an angle of 90 degrees and a distance of 10 centimeters from the mouth. The exposure to the procedures was not randomized.

A pilot study revealed the following values as appropriate for this study: headphone output of $100 \mathrm{~dB}$ - such for amplification as for masking - and a $150 \mathrm{~ms}$ speech delay 16 . Such values were obtained through testing conditions with progressive increments of amplification, masking and delay and were considered sufficient for the selected strategies. The habitual voice was recorded through the method of amplification without auditory feedback.

The speech material was subjected to auditoryperceptual and acoustic analysis. In the auditoryperceptual analysis, the selected parameters were: voice quality, loudness, pitch, overall strain level, speech rate and articulation. The speech material was presented randomly and without identification of the listening condition to five Speech-Language Pathologists (SLP) specialized in voice. The SLPs should judge which utterance section(s) corresponded to the best and worst voice quality; increased and reduced loudness; increased and reduced pitch; higher and lower strain; higher and lower speech rate; better and worse articulation.

To evaluate the intra-subject reliability, $20 \%$ of samples were repeated. The inter-evaluators reliability was measured by the Cronbach Alpha Test.

In the acoustic analysis, the selected parameters were: fundamental frequency (F0), vocal intensity and maximum phonation time (MPT). It was performed with the same speech material of the auditory-perceptual analysis, through the software Vox Metro (version 2.2h, CTS). F0 was measured in $\mathrm{Hz}$; vocal intensity, in $\mathrm{dB}$; and MPT in seconds.

The statistical test used for auditory-perceptual analysis was the chi-square adjusted by Fisher Statistics. For the acoustic analysis, the Wilcoxon test of signalized posts and Mann-Whitney test were used. The software Statistical Package for Social Sciences (SPSS) version 13.0 was used. The significance level adopted was of 5\% (0.050).

\section{Resultados}

The results of the study are presented in Tables 1 and 2. 
TABLE 1. Auditory-Perceptual analysis of habitual voice and conditions of amplification, delay and masking, according to gender.

\begin{tabular}{|c|c|c|c|c|c|c|c|}
\hline \multicolumn{3}{|c|}{ Auditory Parameters } & Significance (p) & \multicolumn{3}{|c|}{ Auditory Parameters } & Significance $(p)$ \\
\hline $\begin{array}{l}\text { Voice Quality } \\
\text { Male }\end{array}$ & Improvement & Worsening & (p) & $\begin{array}{l}\text { Strain } \\
\text { Male }\end{array}$ & Increase & Decrease & (p) \\
\hline Habitual & 12 & 24 & 0,007 & Habitual & 9 & 44 & $<0,001$ \\
\hline Amplification & 14 & 18 & 0,480 & Amplification & 7 & 20 & 0,031 \\
\hline Delay & 7 & 36 & $<0,001$ & Delay & 3 & 24 & 0,007 \\
\hline Masking & 49 & 10 & $<0,001$ & Masking & 58 & 3 & $<0,001$ \\
\hline TOTAL & 82 & 88 & & TOTAL & 77 & 91 & \\
\hline Female & & & & Female & & & \\
\hline Habitual & 11 & 14 & 0,747 & Habitual & 11 & 10 & 0,875 \\
\hline Amplification & 9 & 15 & 0,298 & Amplification & 10 & 11 & 0,738 \\
\hline Delay & 8 & 31 & $<0,001$ & Delay & 4 & 32 & $<0,001$ \\
\hline Masking & 33 & 10 & $<0,001$ & Masking & 34 & 4 & $<0,001$ \\
\hline TOTAL & 61 & 70 & & TOTAL & 59 & 57 & \\
\hline Loudness & Increase & Decrease & (p) & Spech Rate & Increase & Decrease & (p) \\
\hline Male & & & & Male & & & \\
\hline Habitual & 7 & 44 & $<0,001$ & Habitual & 11 & 32 & $<0,001$ \\
\hline Amplification & 14 & 25 & 0,058 & Amplification & 9 & 22 & 0,008 \\
\hline Delay & 6 & 30 & $<0,001$ & Delay & 8 & 22 & 0,006 \\
\hline Masking & 59 & 4 & $<0,001$ & Masking & 49 & 8 & $<0,001$ \\
\hline TOTAL & 86 & 103 & & TOTAL & 77 & 84 & \\
\hline Female & & & & Female & & & \\
\hline Habitual & 11 & 10 & 0,651 & Habitual & 6 & 12 & 0,287 \\
\hline Amplification & 6 & 27 & $<0,001$ & Amplification & 14 & 17 & 0,522 \\
\hline Delay & 8 & 31 & $<0,001$ & Delay & 1 & 41 & $<0,001$ \\
\hline Masking & 37 & 0 & $<0,001$ & Masking & 47 & 1 & $<0,001$ \\
\hline TOTAL & 62 & 68 & & TOTAL & 68 & 71 & \\
\hline $\begin{array}{l}\text { Pitch } \\
\text { Male }\end{array}$ & Increase & Decrease & (p) & $\begin{array}{l}\text { Articulation } \\
\text { Male }\end{array}$ & Improvement & Worsening & (p) \\
\hline Habitual & 11 & 39 & $<0,001$ & Habitual & 5 & 29 & $<0,001$ \\
\hline Amplification & 9 & 26 & 0,001 & Amplification & 13 & 17 & 0,511 \\
\hline Delay & 5 & 26 & 0,001 & Delay & 7 & 36 & $<0,001$ \\
\hline Masking & 56 & 3 & $<0,001$ & Masking & 55 & 5 & $<0,001$ \\
\hline TOTAL & 81 & 94 & & TOTAL & 80 & 87 & \\
\hline Female & & & & Female & & & \\
\hline Habitual & 8 & 11 & 0,551 & Habitual & 12 & 10 & 0,407 \\
\hline Amplification & 6 & 16 & 0,037 & Amplification & 11 & 24 & 0,001 \\
\hline Delay & 7 & 28 & $<0,001$ & Delay & 2 & 31 & $<0,001$ \\
\hline Masking & 39 & 7 & $<0,001$ & Masking & 33 & 1 & $<0,001$ \\
\hline TOTAL & 60 & 62 & & TOTAL & 58 & 66 & \\
\hline
\end{tabular}

Qui-square Test.

\section{Discussion}

The immediate effects observed in conditions of amplification, delay and masking were interesting and evident in individuals with PD once modifications in characteristic symptoms of the disease were observed.

When comparing the habitual voice to the masking condition (Table 1) it can be verified that the voice quality - such in men as in women - improved. This improvement probably occurred due to the increase in loudness $($ men $=59$ and women $=37$ ), strain $($ men $=58$ and women $=34)$ and due to a more precise articulation $($ men $=55$ and women $=33)$. It should be noted that the evaluators could have selected more than one utterance segment for each auditory parameter, which justifies the fact that the values mentioned above are higher than the total number of participants of the study (26). The loudness increase can be explained by a reflex response to masking - named Lombard effect 6-11. By increasing the strain, an improvement in glottic closure occurred, and, consequently, a more projected, less breathy, and possibly, richer in harmonics voice - thus more stable and socially acceptable - was produced.

It can also be observed, in the present study, that the increase in vocal intensity has direct association with a more precise articulation, as reported by Ramig et al. 5 and Carrara et al.17. Similarly to such studies, 
TABLE 2. Acoustic analysis of habitual voice and conditions of amplification, delay and masking, according to gender.

\begin{tabular}{|c|c|c|c|c|c|c|c|}
\hline \multirow{2}{*}{$\begin{array}{c}\text { Acoustic } \\
\text { Parameters }\end{array}$} & \multicolumn{2}{|c|}{ Male } & \multicolumn{2}{|c|}{ Female } & \multicolumn{2}{|c|}{ Total } & \multirow{2}{*}{$\begin{array}{c}\text { Significance } \\
\text { (p) }\end{array}$} \\
\hline & Mean & SD & Mean & SD & Mean & SD & \\
\hline \multicolumn{8}{|l|}{$\mathrm{F}_{0}$} \\
\hline Habitual & 150,6 & 23,59 & 197,3 & 21,62 & 170,3 & 32,43 & $<0,001$ \\
\hline Amplification & 157,7 & 29,22 & 198,9 & 21,20 & 175,2 & 33,01 & 0,001 \\
\hline Delay & 153,0 & 22,06 & 200,5 & 21,07 & 173,1 & 32,00 & $<0,001$ \\
\hline Masking & 164,3 & 26,96 & 207,3 & 24,07 & 182,5 & 33,29 & 0,001 \\
\hline \multicolumn{8}{|l|}{ Intensity } \\
\hline Habitual & 50,5 & 6,98 & 52,3 & 5,10 & 51,3 & 6,21 & 0,350 \\
\hline Amplification & 51,1 & 6,37 & 52,0 & 5,02 & 51,5 & 5,74 & 0,640 \\
\hline Delay & 51,3 & 7,70 & 53,0 & 6,59 & 52,0 & 7,16 & 0,364 \\
\hline Masking & 54,3 & 5,66 & 55,7 & 7,74 & 54,9 & 6,51 & 0,659 \\
\hline \multicolumn{8}{|l|}{ MPT } \\
\hline Habitual & 19,0 & 6,53 & 16,9 & 5,69 & 18,2 & 6,16 & 0,533 \\
\hline Amplification & 18,3 & 6,08 & 16,5 & 6,66 & 17,5 & 6,26 & 0,484 \\
\hline Delay & 20,8 & 5,71 & 19,7 & 6,64 & 20,3 & 6,01 & 0,775 \\
\hline Masking & 18,7 & 6,34 & 16,5 & 6,87 & 17,8 & 6,53 & 0,392 \\
\hline
\end{tabular}

Mann-Whytney Test - Wilcoxon test of signalized posts: habitual F0 x amplification 0.360; habitual intensity $\mathrm{x}$ amplification 0.936; habitual MPT $\mathrm{x}$ amplification 0.036; habitual $\mathrm{x}$ amplification 0.069; habitual $\mathrm{x}$ amplification 0.322; habitual $\mathrm{x}$ amplification 0.001; habitual $\mathrm{x}$ amplification <0.001; habitual $\mathrm{x}$ amplification <0.00; habitual $\mathrm{x}$ amplification 0.446 .

the intensity increase fired an improvement in all speech subsystems, including articulation, without the need for a direct treatment of the last.

In contrast to the masking condition, the delay condition (Table 1) proved to be the worst listening condition once it deregulates the entire phonoarticulatory pattern. In this study, decrease in vocal quality $($ men $=36$ and women $=31)$, loudness $($ men $=30$ and women $=31)$, strain $($ men $=24$ and women $=32)$ and speech rate $($ men and women $=22=$ 41 ), and worsening in articulation ( $m e n=36$ and women $=31$ ) could be observed. Reduction in speech rate occurred in the delay condition - which can be explained by the Lee effect 6-7.

The modifications observed in delay condition are similar to modifications expected in normal individuals. Studies have indicated that the condition of listening produces a positive impact, particularly in individuals who present palilalia and festinating speech 6 , by promoting a reduction in speech rate.

It was verified, in the present study, that positive effects can also be observed for patients with hypokinetic dysarthria without such speech alterations. However, when the voice intensity was too reduced, this strategy did not promote observable improvements.
Similarly to the delay condition, the amplification condition (Table 1) offered unsatisfactory modifications. Loudness was reduced (men $=25$ and women $=27$ ). Such reduction can be justified by the tendency to decrease voice intensity when one hears his own voice amplified 6-7. This approach generally presents benefits for individuals with hyperkinetic dysphonia through the use of high intensity voice. Therefore, delay and amplification showed similar results - as opposite to the ones of masking.

In conditions of masking, delay and amplification, men and women with PD presented similar responses when subjected to effects of auditory feedback. In conditions of delay and amplification, the subjects produced similar immediate modifications, different from those observed in the condition of masking. Therefore, men and women presented similar settings in different listening conditions.

It is important to highlight that the acoustic analysis corroborated the findings of the auditoryperceptual analysis. It was observed that the fundamental frequency (Table 2), showed statistically significant changes for both men and women with PD in all listening conditions ( $p=0.001$ for amplified and masked and $\mathrm{p}<0.001$ for delayed).

It was verified that, in the condition of masking (Table 2), there was an increase in the fundamental frequency $(\mathrm{men}=164.3 \mathrm{~Hz}, \mathrm{SD}=26.96$ and women $=$ $207.3 \mathrm{~Hz}$; SD = 24.07) - similar response to normal subjects. In a study carried out with healthy men, an increase in the fundamental frequency was observed when participants were subjected to pure tone masking 11.

In general, fundamental frequency and voice intensity (Table 2) showed significant differences in the condition of masking, with increase in fundamental frequency $(\mathrm{men}=164.3 \mathrm{~Hz}, \mathrm{SD}=26.96$ and women $=$ $207.3 \mathrm{~Hz}, \mathrm{SD}=24.07)$ and intensity $(\mathrm{men}=54.3 \mathrm{~dB}, \mathrm{SD}$ $=5.66$ and women $=55.7 \mathrm{~dB}, \mathrm{SD}=7.74)$. In the condition of delay, an increase in the MPT $($ men $=20.8 \mathrm{~s}, \mathrm{SD}=$ 5.71 and women $=19.7 \mathrm{~s}, \mathrm{SD}=6.64$ ) was observed.

It is concluded that individuals with PD presented adjustments similar to those of normal individuals when subjected to modified auditory feedback. Therefore, it can be affirmed that the voice of individuals with PD is flexible: it allows the auditory feedback immediate impact - which can be used in speech therapy and serve as a model and incentive for voice treatment. 
Moreover, the use of this technique can provide short and long term improvement in voice and speech of individuals with PD. Individuals with PD with weak voice may present increased loudness when subjected to auditory masking, and, if they present palilalia and festinating speech, they can benefit from the delay condition, which promotes the reduction of speech rate.

\section{References}

1. Limongi JCP. Doença de Parkinson: aspectos clínicos. Fono Atual. 1997;2:9-11.

2. Colton R, Casper J. Compreendendo os problemas da voz: uma perspectiva fisiológica ao diagnóstico e ao tratamento. Porto Alegre: Artes Médicas; 1996.

3. Limongi JCP. Problemas de comunicação e deglutição na doença de Parkinson. Fono Atual. 1998;5:9-10.

4. Silveira DN, Brasolotto AG. Reabilitação vocal em pacientes com doença de Parkinson: fatores interferentes. Pró-Fono R. Atual. Cient. 2005;17(2):241-50.

5. Ramig LO, Bonitati C, Lemke J, Horii Y. Voice treatment for patients with Parkinson's disease: development of an approach and preliminary efficacy data. J Med Speech Pathol. 1994;3:191-209.

6. Behlau M, Madazio G, Feijó D, Azevedo R, Gielow I, Rehder MI. Aperfeiçoamento vocal e tratamento fonoaudiológico das disfonias. In: Behlau M. Voz: o livro do especialista. vol 2. Rio de Janeiro: Revinter; 2005. p. 409-564.

7. Siegel GM, Schork EJ Jr, Pick HL Jr, Garber SR. Parameters of auditory feedback. J Speech and Hearing Research. 1982;25:473-5.

8. Pick HL Jr, Siegel GM, Fox PW, Garber SR, Kearney JK. Inhibiting the Lombard effect. J Acoust Soc Am. 1989;85: 894-900.

9. Adams SG, Lang AE. Can the Lombard effect be used to improve low voice intensity in Parkinsons disease? Eur J Disord Commun. 1992;27(2):121-7.

\section{Conclusion}

The analysis of the effects of modifications on the auditory feedback of the voice of individuals with PD indicates that the condition of masking can offer immediate benefits. The masking condition can be used in Speech Therapy once it provides voice with higher intensity and more precise articulation. In contrast, the amplification and delay conditions presented modifications that do not contribute to minimizing the deviations observed in these patients. No between gender difference was observed in any of the auditory feedback conditions.

10. Quedas A, Duprat AC, Gisele Gasparini G. Implicações do efeito Lombard sobre a intensidade, freqüência fundamental e estabilidade de voz de indivíduos com doença de Parkinson. Rev. Bras. Otorrinolaringol. 2007;73(5):675 -83 .

11. Lee SH, Lee KC, Ban JH, Lee NH, Jin SM. Vocal analysis related to changes in frequency of pure tone auditory feedback. Yonsei Med J. 2008;49(4):610-4.

12. Hoehn MM, Yahr MD. Parkinsonism onset, progression and mortality. Neurology. 1967;17:427-42.

13. Davis H. Abnormal hearing and deafness. In: Davis $H$, Silvermann RS. Hearing and deafness. New York: Holt, Rinehart and Winston; 1970. 3rd ed. p. 83-139.

14. Dejonckere P, Remacle M, Freznel-Elbaz E. Reliability and relevance of differentiated perceptual evaluation of pathological voice quality. In Clemente MP (Ed.): Voice Update. Amsterdam: Elsevier. 1996;321-4.

15. Costa MDL, Gonçalves LR, Barbosa ER, Bacheschi LA. Alterações de neuroimagem no parkinsonismo: estudo de cinco casos. Arq. Neuro-Psiquiatr. 2003;61(2):381-6.

16. Blanchet, PG. Factors influencing the efficacy of delayed auditory feedback in treating dysarthria associated with Parkinson's disease [dissertação]. Louisiana: Louisiana State University and Agricultural and Mechanical College; 2002.

17. Carrara AE, Mourão LF, Ferraz HB, Behlau, MS, Pontes PAL, Andrade LAF. Effect of voice rehabilitation on oral communication of Parkinson's disease patients. Acta Neurologica Scandinavica. 1997;96:199-205. 